\section{Distribution of Urea-derived Nitrogen Supplied to Apple Leaves}

\author{
Habib Khemira ${ }^{1}$, Timothy L. Righetti ${ }^{2}$, and Anita N. Azarenko ${ }^{2}$ \\ Department of Horticulture, Oregon State University, Corvallis, OR 97331-7304
}

Additional index words. Malus $\times$ domestica, urea, ${ }^{15} \mathrm{~N}$, fertilization

\begin{abstract}
Fruit tree responses to foliar urea sprays are variable. We hypothesized that such variability is a function of leaf age-related changes in urea- $\mathrm{N}$ mobility after urea is absorbed. Two experiments were conducted to study the distribution of urea-derived $\mathrm{N}$ in shoots and branches of apple (Malus $\times$ domestica Borkh.) trees. Urea labeled with ${ }^{15} \mathbf{N}$ was applied to young expanding leaves in spring and to senescing spur leaves in fall. At the low concentrations used $[0.5 \%, 1 \%$, and $2 \%(w / v)]$, very little spring-applied ${ }^{15} \mathrm{~N}$ was found in tissues other than the treated leaf. Fall-applied urea- ${ }^{15} \mathrm{~N}$, however, was detected in high concentrations in dormant buds and bark of the spurs to which the treated leaves were attached. Almost no $\mathrm{N}$ was exported to neighboring tissues. The following spring, there was some redistribution of labeled $\mathrm{N}$ to adjacent buds. Foliar urea sprays applied immediately after harvest contributed most to bud $\mathrm{N}$; less urea-N was exported to the buds following later fall applications.
\end{abstract}

The effectiveness of spring-applied foliar urea sprays for fruit trees is controversial. Some researchers have claimed that foliar urea applied in the spring is equally or more effective than soil $\mathrm{N}$ applications in improving fruit set and subsequent fruit size and yield (Blasberg, 1953; Fisher and Cook, 1950). Others have found that the effects of this practice are largely confined to the sprayed leaves and do not affect fruiting or the $\mathrm{N}$ status of the entire tree (Forshey, 1963). We believe that one of the main factors behind this inconsistency is lack of within-plant mobility of ureaderived $\mathrm{N}$ when urea is applied at low concentrations, so as not to injure tender tissues early in the season. Proebsting (1957) found no yield response of pear trees (Pyrus communis L.) to spring foliar-sprays of urea at concentrations ranging from $0.2 \%$ to $0.5 \%(\mathrm{w} / \mathrm{v})$. In contrast, Rejeb et al. (1991) reported increases in yield and shoot growth of 'Bartlett' pear trees after one or two postbloom sprays of a $1.5 \%$ (w/v) urea solution. Sanchez et al. (1990) argued that $\mathrm{N}$ moving into expanding pear leaves is used to build cell structure rather than being incorporated into enzymes or storage compounds. Structural N may be more difficult to remobilize than $\mathrm{N}$ that accumulates in leaves later in the season (Khemira et al., 1998). We hypothesized that, following urea application at low concentrations to young expanding leaves, $\mathrm{N}$ would remain in those leaves and exhibit little, if any, export to other

Received for publication 21 Sep. 1998. Accepted for publication 22 Dec. 1998. Oregon Agricultural Experiment Station technical paper no. 11505. The cost of publishing this paper was defrayed in part by the payment of page charges. Under postal regulations, this paper therefore must be hereby marked advertisement solely to indicate this fact.

${ }^{1}$ To whom reprint requests should be addressed. Current address: 1100 N. Western Ave., Wenatchee, WA 98801-1299. E-mail: habib@wsu.edu ${ }^{2}$ Professor. organs. To investigate this hypothesis, the distribution of $\mathrm{N}$ derived from urea sprayed onto apple leaves in spring and autumn was studied.

Since Oland (1960) first introduced the use of autumn urea sprays to increase the $\mathrm{N}$ reserves of apple trees, a considerable amount of literature has accumulated on the subject (O'Kennedy et al., 1975; Oland, 1960, 1963; Sanchez et al., 1990; Shim et al., 1972, 1973; Williams, 1965). However, the relationship between time of urea application in the fall and translocation efficiency of the resulting $\mathrm{N}$ has received little attention. Since leaves may be injured and photosynthetic capacity of the tree decreased after spraying, a late application of urea may be more favorable than an early one. However, following a late fall application of urea, maturation of the abscission zone and severance of the vascular connections between the leaf petiole and the stem or spur may limit movement of Ninto the tree (Hill-Cottingham, 1968). We hypothesized that urea sprays applied during late stages of leaf senescence would be least efficient in providing $\mathrm{N}$ to the bud. We therefore initiated an experiment to study the relationship between time of urea application in the fall and movement of urea$\mathrm{N}$ from leaves to buds.

\section{Materials and Methods}

Expt. 1. Mobility of urea-derived $N$ from young leaves. Four weeks after bloom (28 Apr. 1994), aqueous solutions of ${ }^{15} \mathrm{~N}$-depleted urea $\left(0.01\right.$ atom $\%{ }^{15} \mathrm{~N}$ ) (Isotec, Miamisburg, Ohio) at $0.5 \%, 1 \%$, or $2 \%(\mathrm{w} / \mathrm{v})$ concentration were painted with a brush onto both sides of two young expanding shoot leaves $(\approx 2 \mathrm{~cm}$ long and $30 \%$ of final size) on each of nine, single replicate, 4-year-old 'Golden Delicious' apple trees on M.7A rootstock. The solutions contained $0.1 \%(\mathrm{v} / \mathrm{v})$ nonionic surfactant Triton X100. Each treatment was applied to three randomly selected trees in the plot. Four weeks later, the following plant material was col- lected from one of the two shoots with a treated leaf: 1) the treated leaf, 2) the older leaf immediately below, 3) a younger leaf from the shoot-tip ( $\approx 8 \mathrm{~cm}$ away), 4$)$ a 2 -cm-long stem section $1 \mathrm{~cm}$ below the treated leaf, and 5) a similar section $1 \mathrm{~cm}$ above the treated leaf. These two stem sections were combined into one sample. The section of the shoot bearing the treated leaf was discarded to preclude any direct contamination with ${ }^{15} \mathrm{~N}$ from runoff during application. This sampling was repeated 6 weeks later.

After sampling, tissues were carefully washed with $0.1 \%$ Alconox detergent (Alconox, New York) and thoroughly rinsed once with warm tap water and once with deionized water to remove residual urea from external surfaces. The samples were then ovendried at $60^{\circ} \mathrm{C}$ for at least $3 \mathrm{~d}$ and ground to pass a 40-mesh screen before the isotopic composition was determined by mass spectrometry at Isotope Services (Los Alamos, N.M.). Atom percent ${ }^{15} \mathrm{~N}$ values were converted to nitrogen derived from the fertilizer (NDFF) using the following formula (adapted from Hauck and Bremner, 1976):

$$
\text { NDFF }=\frac{\left({ }^{15} \mathrm{~N}_{\text {natural abundance }}\right)-\left(\text { atom } \%{ }^{15} \mathrm{~N}\right)_{\text {tissue }}}{\left({ }^{15} \mathrm{~N}_{\text {natural abundance }}\right)-\left(\text { atom } \%{ }^{15} \mathrm{~N}\right)_{\text {urea }}}
$$

where ${ }^{15} \mathrm{~N}_{\text {natural abundance }}$ was considered equal to 0.37 atom percent. Data were analyzed as a completely randomized design using PROC GLM (SAS 6.12; SAS Institute, Cary, N.C.).

Expt. 2. Mobility of urea-derived $N$ from fall foliar applications. In 1992, shortly after harvest (7 Oct.), 15 spurs of comparable size and one branch were selected on each of three, single replicate, 8-year-old 'Golden Delicious' apple trees on M.7A rootstock. The leaves were still green. The spurs and branches were sprayed individually with a $7.5 \%(\mathrm{w} / \mathrm{v})$ aqueous solution of urea enriched in ${ }^{15} \mathrm{~N}(1.346$ atom $\left.\%{ }^{15} \mathrm{~N}\right)$. The solution contained $0.1 \%(\mathrm{v} /$ v) Triton X100. Branches and spurs surrounding the treated tissues and the ground under the tree were covered with plastic sheets to preclude any contamination with labeled urea. The treated spurs and branches were then covered with plastic bags and the whole trees sprayed to runoff with a $7.5 \%(\mathrm{w} / \mathrm{v})$ solution of nonlabeled urea. Fallen leaves were removed from under the trees to prevent ground contamination with ${ }^{15} \mathrm{~N}$. On 23 Dec., five buds and 2-cm-long strips of surrounding bark from the individually treated spurs and five others from the treated branches were collected from each tree. Additionally, buds and bark $10 \mathrm{~cm}$ below (proximal 1) or above (distal 1) and those 20 $\mathrm{cm}$ below (proximal 2) or above (distal 2) a treated spur were sampled. Buds and bark were also sampled from an adjacent and a distant branch. This sampling was repeated at full bloom (12 Apr. 1993) and the following winter (4 Jan. 1994). The buds and bark strips were washed, processed, and analyzed as in Expt. 1. Data from each sampling date were analyzed separately as a randomized complete-block design (each tree was a block) using PROC GLM (SAS 6.12; SAS Institute). 
Expt. 3. Effect of timing of fall application on urea-derived $N$ export. On 10 Oct. 1994, the leaves of eight spurs on each of four, single replicate, mature 'Red Delicious'/M.7A apple trees were dipped in a $5 \%(\mathrm{w} / \mathrm{v})$ aqueous solution of urea enriched in ${ }^{15} \mathrm{~N}$ (10 atom \% $\left.{ }^{15} \mathrm{~N}\right)$. The same treatment was repeated on 1 and 18 Nov. 1994 on new sets of spurs on the same trees. Leaf fall started on 1 Nov. and the trees had lost $50 \%$ of their leaves by 18 Nov. All treatments were applied in the mornings of sunny days, but the average day temperature was lower on 18 Nov. than on the earlier dates. Buds from the treated spurs were collected on 3 Jan. 1995. They were promptly washed, oven-dried, and analyzed as in Expt 1.

\section{Results and Discussion}

Expt 1. Mobility of urea-derived $N$ from young leaves. Treated leaves reached their final size within 1 month after application of ${ }^{15} \mathrm{~N}$-urea. Overall, ${ }^{15} \mathrm{~N}$ was largely restricted, for the duration of the experiment, to the leaf where it was applied (Table 1). Similar results were obtained 10 weeks after application (data not shown). Little ${ }^{15} \mathrm{~N}$ label was recovered in leaves sprayed with the $0.5 \%$ urea solution, but following the $1 \%$ treatment, treated leaves showed 5.0\% NDFF, and this increased to $10.1 \%$ when the urea concentration was doubled. Whether failure to detect ${ }^{15} \mathrm{~N}$ in leaves following postbloom application of $0.5 \%$ urea was due to limited absorption or excessive dilution of the label within the expanding leaves is not clear. However, uptake of solutes across the leaf cuticle is directly proportional to concentration of the spray solution (Kannan, 1986). In pear trees, no yield response to spring foliar urea was obtained using concentrations ranging from $0.2 \%$ to $0.5 \%$ (Proebsting, 1957). Repeated applications of low concentrations of urea are sometimes effective in improving yield; Blasberg (1953) reported higher yields for 'McIntosh' apple with four sprays of a $0.6 \%$ urea solution in spring, but the response was less with three sprays.

The leaves immediately below or above, and the stem-sections $1 \mathrm{~cm}$ away from, the treated leaves had only small percentages of NDFF (Table 1). These results are in agreement with earlier reports of immobility of urea- $\mathrm{N}$ from spring foliar sprays (Forshey,

Table 1. Effect of concentration of postbloom ${ }^{15} \mathrm{~N}$ urea sprays on the enrichment (\% $\mathrm{N}$ derived from fertilizer) of the treated leaves and adjacent younger and older leaves and bark. Urea was applied with a brush to the leaves when they were young and still expanding. The samples were taken 1 month later.

\begin{tabular}{lccc}
\hline & \multicolumn{3}{c}{ Concn of urea solution $(\% \mathrm{w} / \mathrm{v})$} \\
\cline { 2 - 4 } Tissue & 0.5 & 1 & 2 \\
\hline Younger leaf & $0.1 \mathrm{a}^{\mathrm{z}}$ & $0.7 \mathrm{~b}$ & $0.9 \mathrm{~b}$ \\
Treated leaf & $0.1 \mathrm{a}$ & $5.0 \mathrm{a}$ & $10.1 \mathrm{a}$ \\
Older leaf & $0.2 \mathrm{a}$ & $0.3 \mathrm{~b}$ & $0.3 \mathrm{~b}$ \\
Stem & $0.3 \mathrm{a}$ & $0.2 \mathrm{~b}$ & $0.2 \mathrm{~b}$ \\
\hline
\end{tabular}

${ }^{2}$ Mean of three replicates, separation within columns by Duncan's multiple range test, $P \leq 0.05$.
1963). Mobility of urea-derived $N$ varies with the physiological age of sprayed leaves. The lack of mobility of urea-derived $\mathrm{N}$ in our study may be an extreme case compared with what is reported elsewhere. Unlike other investigations, we used only young shoot-leaves $(<30 \%$ of their final size). Our study did not address whether urea sprayed on more mature leaves is mobile early in the season. However, Sanchez and Righetti (1990) found that little of soilderived leaf $\mathrm{N}$ was exported out of pear leaves until late in the season, and that the net efflux of endogenous $\mathrm{N}$ did not start until onset of senescence in October in Medford, Ore.

In some cases, lack of effectiveness of urea treatments may be due to spray solutions being too dilute to contribute effectively to tree $\mathrm{N}$ budget. Differences in urea mobility due to differences in leaf age could also explain inconsistent responses to spring foliar sprays.

Expt. 2. Mobility of urea-derived $N$ from fall foliar applications. Ten weeks after urea application (23 Dec.), a substantial fraction of the $\mathrm{N}$ content of dormant flower buds from both individually sprayed spurs and branches was derived from the applied urea $(16.1 \%$ and $38.5 \%$ NDFF, respectively, Table 2). However, very little labeled $\mathrm{N}$ was found in buds on spurs either above or below those treated. Similarly, buds from branches adjacent to the ${ }^{15} \mathrm{~N}$-sprayed branch contained negligible amounts of label(Table 2). The treated branches had higher percentages of NDFF than the individually treated spurs because they were sprayed more liberally. With the spurs, we were careful not to contaminate the leaves of adjacent spurs and applied a lower volume of treatment solution (data not shown).

Our data clearly indicated limited movement of urea-derived $\mathrm{N}$ beyond the tissues where it was applied. Similar results were reported for 'Comice' pear (Sanchez et al., 1990). This differs from previous reports by Shim et al. (1973) and Swietlik and Faust (1984). In both studies, some foliarly applied urea or its metabolites was translocated to the roots within a few days after application. However, they used young apple seedlings or rooted cuttings, which have limited storage capacity. We believe that older bearing trees, with larger $\mathrm{N}$ storage sites, behave differently from much smaller plants. Extrapolation of data on $\mathrm{N}$ transport and distribution from small to mature trees may be inappropriate.
By Spring 1993, the percentage of ${ }^{15} \mathrm{~N}$ in the treated buds had decreased considerably, although the NDFF values were still higher than those in neighboring buds (Table 2). This decrease could be a dilution effect due to mobilization of unlabeled storage $\mathrm{N}$ from surrounding bark and wood, or a sharing of the label with adjacent buds. The NDFF values for treated buds had declined further by the following winter (Jan. 1994). Although urea-N remains near the site of its absorption during the first fall and winter after application, it is probably redistributed throughout the apple tree in subsequent years, as is the case for pears (Sanchez et al., 1990). Declining NDFF was expected, since labeled $\mathrm{N}$ was probably exported in the harvested fruit and senescent leaves, incorporated into the perennial parts of the tree and/or diluted with $\mathrm{N}$ from unlabeled sources.

Postharvest urea sprays may provide a valuable method to target buds and their surrounding tissues. This practice increases $\mathrm{N}$ reserves available for the buds without the excessive vigor often associated with heavy groundapplications of $\mathrm{N}$ fertilizers early in the season.

Expt. 3. Effect of timing of fall application on urea-derived $N$ export. The 10 Oct. spray was the most effective of the three application dates in providing $\mathrm{N}$ for the buds (Fig. 1). The NDFF of winter buds of the spurs sprayed on this date $(26.4 \%)$ was about five times as high as the following treatments on subsequent dates $(6.7 \%$ and $4.8 \%)$. Since all buds were similar in size and total $\mathrm{N}$ concentration (data not shown), a higher percentage of NDFF translates into a higher urea-derived $\mathrm{N}$ content. Oland (1963) found no difference in $\mathrm{N}$ content of dormant buds from 'Gravenstein' apple trees that received a foliar application of $4 \%$ urea either in September or October. However, the two applications were applied earlier in the season, separated by only 2 weeks, and the more sensitive ${ }^{15} \mathrm{~N}$ tracer was not used. As leaves senesce (in November), they probably become less efficient at absorbing and exporting urea (or its metabolites) (Cook and Boynton, 1952). Since foliar urea sprays may damage fruit, preharvest applications are not recommended. However, foliar applications should be made as soon after harvest as possible to maximize uptake and transport. Differences in uptake and translocation efficiency

Table 2. Effect of postharvest application of 7.5\% (w/v) ${ }^{15} \mathrm{~N}$-enriched urea on 7 Oct. 1992 on the enrichment $\left(\% \mathrm{~N}\right.$ derived from fertilizer $\left.{ }^{\mathrm{z}}\right)$ of bud and bark in proximal and distal spurs and in treated, adjacent, and distant spurs and branches.

\begin{tabular}{llcccc}
\hline Sprayed & Position of & \multicolumn{3}{c}{ Buds Sampled: } & Bark Sampled: \\
\cline { 2 - 5 } part & spur or branch & 23 Dec. 92 & 12 Apr. 93 & 4 Jan. 94 & 23 Dec 92 \\
\hline Spur & Distal 2 & $1.1 \mathrm{~b}^{\mathrm{z}}$ & $1.9 \mathrm{~b}$ & $0.4 \mathrm{~b}$ & $0.6 \mathrm{~b}$ \\
& Distal 1 & $1.3 \mathrm{~b}$ & $1.2 \mathrm{~b}$ & $0.4 \mathrm{~b}$ & $0.9 \mathrm{~b}$ \\
& Treated & $16.1 \mathrm{a}$ & $3.5 \mathrm{a}$ & $1.3 \mathrm{a}$ & $3.6 \mathrm{a}$ \\
& Proximal 1 & $1.2 \mathrm{~b}$ & $1.4 \mathrm{~b}$ & $0.4 \mathrm{~b}$ & $0.9 \mathrm{~b}$ \\
& Proximal 2 & $0.8 \mathrm{~b}$ & $1.0 \mathrm{~b}$ & $0.3 \mathrm{~b}$ & $0.4 \mathrm{~b}$ \\
\multirow{2}{*}{ Branch } & Treated & $38.5 \mathrm{a}$ & $13.6 \mathrm{a}$ & $3.6 \mathrm{a}$ & $24.1 \mathrm{a}$ \\
& Adjacent & $0.9 \mathrm{~b}$ & $1.4 \mathrm{~b}$ & $1.0 \mathrm{~b}$ & $0.2 \mathrm{~b}$ \\
& Distant & $0.3 \mathrm{~b}$ & $0.4 \mathrm{~b}$ & $0.3 \mathrm{~b}$ & $0.1 \mathrm{~b}$ \\
\hline
\end{tabular}

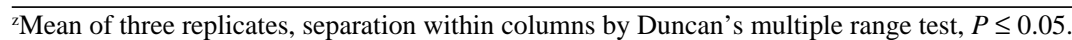

${ }^{y}$ Distal 1 and Distal $2=10$ and $20 \mathrm{~cm}$ proximal from the treated spur, respectively. Proximal 1 and proximal

$2=10$ and $20 \mathrm{~cm}$ proximal from the treatedspur, respectively. 


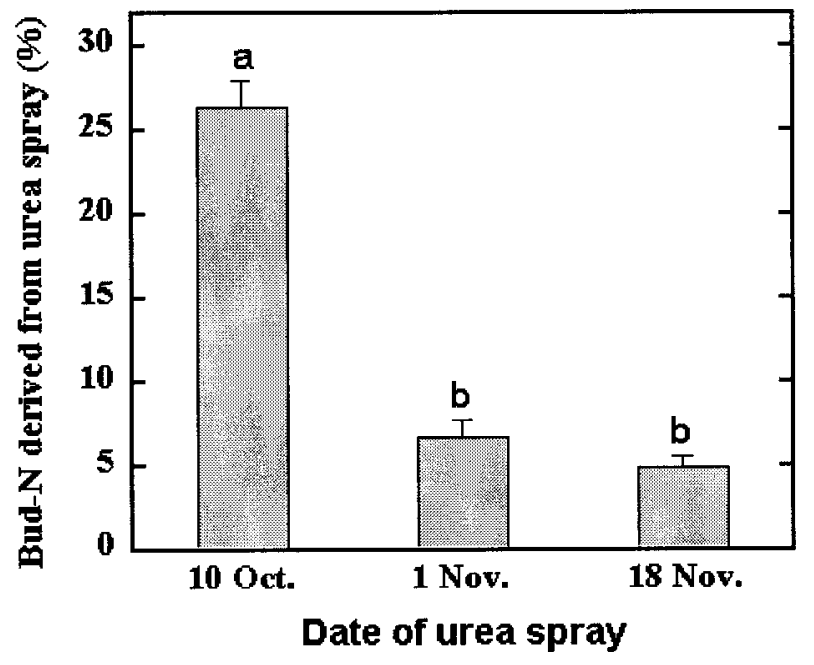

Fig. 1. Effect of application date on urea-derived-N content of dormant apple buds. Vertical bars indicate standards errors about the treatment means $(n=4)$. Treatment means with the same letter are not significantly different as determined by Duncan's multiple range test at $P \leq 0.05$.

may reflect the multitude of internal and environmental factors controlling the initiation and duration of natural leaf senescence. The most important among these factors are genotype, photoperiod, temperature, and plant vigor (Doering and Gericke, 1986).

A postharvest urea application at the beginning of leaf senescence appears to be most efficient in providing $\mathrm{N}$ to the developing flower buds. At the low concentrations [up to $2 \%(\mathrm{w} / \mathrm{v})]$ that can be safely used in spring, little urea-N was transported from young leaves. Fall-applied urea-N, however, was detected in high concentrations in dormant buds and bark of treated spurs, but almost no $\mathrm{N}$ was exported to neighboring tissues. Subsequently, there was some redistribution of labeled $\mathrm{N}$ to adjacent buds the following spring. Fall foliar urea sprays should be applied soon after harvest, as urea absorption and export become less efficient as leaf senescence advances.

\section{Literature Cited}

Blasberg, C.H. 1953. Response of mature McIntosh apple trees to urea foliar sprays in 1950 and 1951. Proc. Amer. Soc. Hort. Sci. 62:147-153.

Cook, J.A. and D. Boynton. 1952. Some factors affecting the absorption of urea by McIntosh apple leaves. Proc. Amer. Soc. Hort. Sci. 59:82-90.

Doering, H.W. and R. Gericke. 1986. The efficiency of foliar fertilization in arid and semi-arid regions, p. 96-125. In: A. Alexander (ed.). Foliar fertilization. Martinus Nijhoff, Dordrecht, The Netherlands.

Fisher, E.G. and J.A. Cook. 1950. Nitrogen fertilization of the McIntosh apple tree with leaf sprays of urea. Proc. Amer. Soc. Hort. Sci. 55:35-40.

Forshey, C.G. 1963. A comparison of soil nitrogen fertilization and urea sprays as sources of nitrogen for apple trees in sand culture. J. Amer. Soc. Hort. Sci. 83:32-45.

Hauck, R.D. and J.M. Bremner. 1976. Use of tracers for soil and fertilizer nitrogen research. Adv. Agron. 28:219-266.
Hill-Cottingham, D.G . 1968. The effect of climate and time of application of fertilizers on the development and crop performance of fruit trees, p. 243-253. In: E.J. Hewitt and C.V. Cutting (eds.). Recent aspects of nitrogen metabolism in plants. Academic, London.

Kannan, S. 1986. Foliar absorption and transport of inorganic nutrients. Crit. Rev. Plant Sci. 4:341374.

Khemira, H., T.L. Righetti, and A.N. Azarenko. 1998. Nitrogen partitioning in apple as affected by timing and tree growth habit. J. Hort. Sci. Biotech. 73:217-223.

O'Kennedy, B.T., M.J. Hennerty, and J.S. Titus. 1975. The effects of autumn foliar urea sprays on storage forms of nitrogen extracted from bark and wood of apple shoots. J. Hort. Sci. 50:331338.

Oland, K. 1960. Nitrogen feeding of apple trees by post-harvest urea sprays. Nature 185:857.

Oland, K. 1963. Responses of cropping apple trees to post-harvest urea sprays. Nature 198:1282-1283.

Proebsting, E.L. 1957. Tree nutrient sprays. Calif. Agr. 11:10.

Rejeb, H., N. Ben Abdelaali, and R. Hellali. 1991. Effets des pulvérisations d'urée sur la production et les réserves minérales du pommier 'Williams'. Revue de l'Institute of National Agriculture Tunisia (I.N.A.T.) 4:111-122.

Sanchez, E.E. and T.L. Righetti. 1990. Tree nitrogen status and leaf canopy position influence postharvest nitrogen accumulation and efflux from pear leaves. J. Amer. Soc. Hort. Sci. 115:934-937.

Sanchez, E.E., T.L. Righetti, D. Sugar, and P.B. Lombard. 1990. Response of 'Comice' pear trees to a postharvest urea spray. J. Hort. Sci. 65:541-546.

Shim, K.K., J.S. Titus, and W.E. Splittstoesser. 1972. The utilization of post-harvest urea sprays by senescing apple leaves. J. Amer. Soc. Hort. Sci. 97:592-596.

Shim, K.K., J.S. Titus, and W.E. Splittstoesser. 1973. The fate of carbon and nitrogen from urea applied to foliage of senescing apple trees. J. Amer. Soc. Hort. Sci. 98:360-366.

Swietlik, D. and M. Faust. 1984. Foliar nutrition of fruit crops. Hort. Rev. 6:287-355.

Williams, R.R. 1965. The effect of summer nitrogen applications on the quality of apple blossoms. J. Hort. Sci. 40:31-41. 